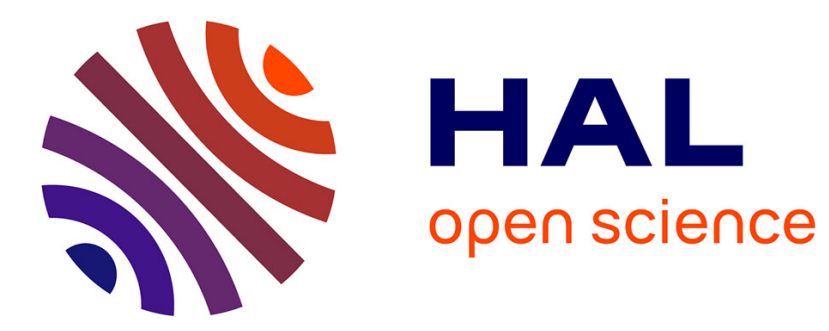

\title{
Proteomic analysis, immunogenicity of secreted proteins from Rhodococcus equi ATCC 33701
}

\author{
Corinne Barbey, Aurélie Budin-Verneuil, Séverine Cauchard, Axel Hartke, \\ Claire Laugier, Vianney Pichereau, Sandrine Petry
}

\section{- To cite this version:}

Corinne Barbey, Aurélie Budin-Verneuil, Séverine Cauchard, Axel Hartke, Claire Laugier, et al.. Proteomic analysis, immunogenicity of secreted proteins from Rhodococcus equi ATCC 33701. Veterinary Microbiology, 2009, 135 (3-4), pp.334. 10.1016/j.vetmic.2008.09.086 . hal-00532518

\section{HAL Id: hal-00532518 https://hal.science/hal-00532518}

Submitted on 4 Nov 2010

HAL is a multi-disciplinary open access archive for the deposit and dissemination of scientific research documents, whether they are published or not. The documents may come from teaching and research institutions in France or abroad, or from public or private research centers.
L'archive ouverte pluridisciplinaire HAL, est destinée au dépôt et à la diffusion de documents scientifiques de niveau recherche, publiés ou non, émanant des établissements d'enseignement et de recherche français ou étrangers, des laboratoires publics ou privés. 


\section{Accepted Manuscript}

Title: Proteomic analysis, immunogenicity of secreted proteins from Rhodococcus equi ATCC 33701

Authors: Corinne Barbey, Aurélie Budin-Verneuil, Séverine Cauchard, Axel Hartke, Claire Laugier, Vianney Pichereau, Sandrine Petry

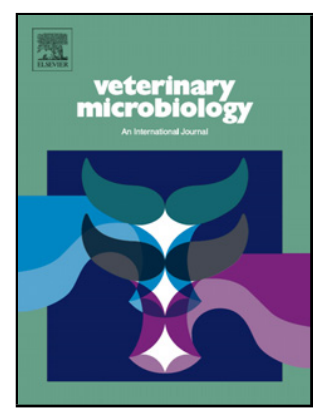

PII: S0378-1135(08)00466-5

DOI: doi:10.1016/j.vetmic.2008.09.086

Reference: VETMIC 4219

To appear in: $\quad$ VETMIC

Received date: $\quad$ 7-8-2008

Revised date: $\quad 19-9-2008$

Accepted date: $\quad$ 24-9-2008

Please cite this article as: Barbey, C., Budin-Verneuil, A., Cauchard, S., Hartke, A., Laugier, C., Pichereau, V., Petry, S., Proteomic analysis, immunogenicity of secreted proteins from Rhodococcus equi ATCC 33701, Veterinary Microbiology (2008), doi:10.1016/j.vetmic.2008.09.086

This is a PDF file of an unedited manuscript that has been accepted for publication. As a service to our customers we are providing this early version of the manuscript. The manuscript will undergo copyediting, typesetting, and review of the resulting proof before it is published in its final form. Please note that during the production process errors may be discovered which could affect the content, and all legal disclaimers that apply to the journal pertain. 
1 Proteomic analysis and immunogenicity of secreted proteins from Rhodococcus equi

8 Corinne Barbey ${ }^{1}$, Aurélie Budin-Verneuil ${ }^{2}$, Séverine Cauchard ${ }^{1}$, Axel Hartke ${ }^{2}$, Claire

10 AFSSA, Laboratoire d'Etudes et de Recherches en Pathologie Equine, IPC, Goustranville,

1114430 Dozulé, France ${ }^{l}$ and Laboratoire de Microbiologie de l'Environnement, USC INRA 2017, EA956, IFR ICORE 146, Université de Caen, 14032 Caen Cedex, France ${ }^{2}$

$16{ }^{*}$ Corresponding author. Mailing address: AFSSA, Laboratoire d'Etudes et de Recherches en

17 Pathologie Equine, IPC, Goustranville, 14430 Dozulé, France. Phone: 33 (0)2 31792276.

18 Fax: 33 (0)2 313921 37. E-mail: s.petry@ dozule.afssa.fr. 
Abstract

Rhodococcus equi is one of the most important causes of mortality in foals between 1 to 6 months of age. Although rare, infection also occurs in a variety of other mammals including humans, often following immunosuppression of various causes. Secreted proteins are known to mediate important pathogen-host interactions and consequently are favored candidates for vaccine development as they are the most easily accessible microbial antigens to the immune system. Here, we describe the results of a proteomic analysis based on SDS PAGE, immunoblot and mass spectrometry, which was carried out aiming the identification of secreted proteins that are differently expressed at $30^{\circ} \mathrm{C}$ versus $37^{\circ} \mathrm{C}$ and at mid-exponential versus early-stationary growth phase and antigenic proteins from $R$. equi ATCC 33701. A total of 48 proteins was identified regardless of growth conditions. The cholesterol oxidase

ChoE appears to be the major secretory protein. Moreover, four proteins revealed high homologies with the mycolyl transferases of the Ag85 complex from Mycobacterium tuberculosis. The sequence analysis predicted that 24 proteins are transported by a signal peptide-dependent pathway. Moreover, five antigenic proteins of $R$. equi were identified by immunoblot, including a novel strongly immunoreactive protein of unknown function. In conclusion, the elucidation of the secretome of $R$. equi identified several proteins with different biological functions and a new candidate for developing vaccines against $R$. equi infection in horse.

39 Keywords: Rhodococcus equi; Secretome; Mass spectrometry; Signal peptide; Antigenic 40 proteins 


\section{Introduction}

Rhodococcus equi is the common cause of pyogranulomatous pneumonia with a high mortality rate in foals up to 6 months of age (Muscatello et al., 2007). Even if the pathogenic mechanisms of $R$. equi remain largely unknown, there is evidence that virulence is dependent on a large plasmid with a pathogenicity island (Takai et al., 2000; Takai et al., 1991b), containing nine virulence-associated protein (vap) genes (Muscatello et al., 2007). Among them, vapA encodes a surface-expressed protein (Takai et al., 1991a; Tan et al., 1995), which plays a crucial role in intracellular growth in macrophages and for disease development (Giguère et al., 1999; Jain et al., 2003).

\section{Secreted proteins are of high interest for functional investigations of bacterial pathogens} because they come into direct contact with host tissues. Particularly, secreted proteins of intracellular pathogens such as $R$. equi represent the primary antigen targets of host immune response (Kaufmann and Hess, 1999). Thus, they may be key molecules to induce immune protection and, consequently, key candidates for vaccine development. Few data are available about $R$. equi and only five secreted proteins were described such as the cholesterol oxidase ChoE and the phospholipase $\mathrm{C}$, two membrane-damaging exoenzymes, originally called equi factors (Machang'u and Prescott, 1991a), and three virulence-associated proteins VapC, VapD and VapE (Byrne et al., 2001) of still unknown function.

The goal of the present study was to identify proteins secreted by $R$. equi ATCC 33701 at different temperatures $\left(30^{\circ} \mathrm{C}\right.$, the optimal growth temperature, versus $37^{\circ} \mathrm{C}$, the host temperature) and at different growth phases (mid-exponential versus early-stationary phase of growth). Bioinformatic study was carried out to predict the functions and to confirm the extracellular localization of the identified proteins. Furthermore, immunogenic secreted proteins expressed during equine rhodococcosis were characterized by using Western blot probed with pooled sera from nine foals which died from $R$. equi infection. 


\section{Materials and methods}

68

69

\section{1. Bacteria and culture conditions}

The bacterial strain used in experiments was $R$. equi ATCC 33701, a virulence plasmidbearing strain. A single colony was selected and grown in $10 \mathrm{ml}$ of Luria Bertani (LB, Difco, Le Pont de Claix, France) medium for $16 \mathrm{~h}$ at $30^{\circ} \mathrm{C}$ or $37^{\circ} \mathrm{C}$, at $\mathrm{pH} 7.0$ with shaking at 200 rpm. Cultures were inoculated at a 1:100 dilution with the preculture. Samples $(500 \mathrm{ml})$ were taken in mid-exponential $\left(\mathrm{OD}_{600}\right.$ of 0.4 to 0.5$)$ and early-stationary ( $\mathrm{OD}_{600}$ of 0.7 to 0.8 ) growth phases, respectively after 15 and $22 \mathrm{~h}$ of incubation with shaking at $200 \mathrm{rpm}$.

E. coli BL21(DE3) (Novagen, Merck, Darmstadt, Germany) and E. coli M15 (Qiagen, Courtaboeuf, France) were used for protein expression.

\section{2. Extracellular sample preparation for the proteome analysis}

Cultures were centrifuged at $20,000 \mathrm{~g}$ for $30 \mathrm{~min}$ at $4{ }^{\circ} \mathrm{C}$ and the supernatants were sterile filtered by using a $0.2-\mu \mathrm{m}$ nitrocellulose filter (Millipore, Molsheim, France). Then a final concentration of $10 \%(w / v)$ trichloroacetic acid (TCA, Sigma, St Quentin Fallavier, France) was added to the filtrate supernatant, mixed well and placed on ice at $4^{\circ} \mathrm{C}$ for $16 \mathrm{~h}$. The precipitated proteins were harvested by centrifugation $\left(20,000 \mathrm{~g}\right.$ for $30 \mathrm{~min}$ at $\left.4^{\circ} \mathrm{C}\right)$, washed four times in cold methanol (Fluka, quality upgraded, St Quentin Fallavier, France) dried with speed-vac and dissolved in sample solution consisting of $0.5 \mathrm{M}$ Tris base $\mathrm{pH} 8.0$ (Sigma). Protein concentration was determined according to the Lowry method (Lowry et al., 1951), using bovine serum albumine (BSA, Sigma) as a standard.

\section{3. SDS PAGE}


90 Proteins samples were denatured in Laemmli Buffer 6\% (v/v) SDS (Eurobio, Les Ulis,

91 France), $16 \%(\mathrm{v} / \mathrm{v})$ glycerol (Eurobio), $0.02 \%(\mathrm{v} / \mathrm{v}) \beta$-mercaptoethanol (Sigma), and $0.08 \%$

92 (w/v) bromophenol blue (Electran, BDH Laboratory Supplies, Poole, UK) in 100 mM Tris-

$93 \mathrm{HCl}$ Buffer pH6.8 by heating to $100^{\circ} \mathrm{C}$ for $5 \mathrm{~min}$. Then samples $(150 \mu \mathrm{g}$ in each well) were

94 separated by one-dimensional denaturing sodium dodecyl sulfate-polyacrylamide gel

95 electrophoresis (SDS-PAGE) with a 7\% acrylamide (29:1 acrylamide/bisacrylamide, Eurobio)

96 stacking gel and a $12 \%$ acrylamide resolving gel. The Bio-Rad prestained broad standard

97 marker was used as a protein molecular weight marker. After electrophoresis using the

98 PROTEAN $^{\circledR}$ II xi Cell (Bio-Rad Laboratories, Marnes-la-Coquette, France) at $150 \mathrm{~V}$ for 15 h,

99 the gel was stained with Coomassie Brilliant Blue R250 (Reactifs Ral, Martillac, France) to

100 visualize the proteins.

101

102

2. 4. In gel-trypsin digestion

103 Protein spots to be identified were manually excised from Coomassie stained gels and

104 excised gel fractions were washed in ultra-pure water. These fractions were then dehydrated

105 by several incubations in $50 \mathrm{mM}$ ammonium bicarbonate (BICAM, Fluka) and acetonitrile

106 (CAN, Merck, Fontenay-sous-Bois, France), followed by rehydration in 50 mM BICAM. 0.5

$107 \mu \mathrm{g}$ modified porcine trypsin (sequencing grade modified trypsin, Promega Corporation,

108 Charbonnières, France) was added to each sample, which was then incubated during $16 \mathrm{~h}$ at

$10937^{\circ} \mathrm{C}$. The supernatant was recovered by centrifugation $(5,000 \mathrm{~g}$ for $5 \mathrm{~min})$. A second

110 extraction from these gel pieces was carried out by incubation in $50 \mathrm{mM}$ BICAM/ACN (1/1 :

$111 \mathrm{v} / \mathrm{v}$ ) and then by incubation in 5\% acetic acid (Carlo Erba, Val de Reuil, France). Peptide-

112 containing liquid fractions were pooled after each incubation and vacuum dried. Peptides

113 were resuspended in $20 \mu 10.1 \%$ acetic acid prior to storage at $-70^{\circ} \mathrm{C}$ until mass spectrometry

114 (MS) analysis. 
116 2. 5. Trypsin digestion of crude extracts of secreted proteins

117 Crude extracts of secreted proteins were obtained as described above from culture 118 supernatants at the early-stationary growth phase $\left(\mathrm{OD}_{600}\right.$ of 0.7 to 0.8$)$ and $30^{\circ} \mathrm{C}$ or $37^{\circ} \mathrm{C}$.

119 Proteins were resuspended in $50 \mathrm{mM}$ BICAM pH 8.0 containing $0.5 \mu \mathrm{g}$ trypsin, incubated at $12037^{\circ} \mathrm{C}$ during $16 \mathrm{~h}$, before being vacuum dried and resuspended in $0.1 \%$ acetic acid. Peptides 121 were stored at $-70^{\circ} \mathrm{C}$ until MS analysis.

122

123 2.6. MS/MS analysis

124 An electrospray ion trap mass spectrometer (LCQ DECA XP, Thermo Finnigan) coupled 125 on line with an HPLC (Surveyor LC, Thermo Finnigan) was used. Peptides were separated 126 and analysed mainly as previously described (Sauvageot et al., 2002). Recorded MS/MS

127 spectra were compared to theoretical fragmentations of a trypsinolysed database deduced 128 from the R. equi 103 DNA genomic sequence, using the Sequest software (version 2, Thermo 129 Finnigan).

130

131 2. 7. Bioinformatic tools to analyze amino acid sequences

132 Protein sequences were obtained thanks to the non-annotated genome sequence of $R$. equi 133 strain 103 produced by the Rhodococcus equi Sequencing Group at the Sanger Institute 134 (http://www.sanger.ac.uk/Projects/R_equi/). For unknown proteins, homologous proteins 135 were identified using the BLASTP program available at the website 136 http://www.ncbi.nlm.nih.gov/BLAST/sequence. Conserved protein domains were identified 137 by using CDD software based $\quad$ on

138 (http://www.ncbi.nlm.nih.gov/Structure/cdd/cdd.shtml). 
139 The secretory (Sec-type) signal peptides were determined with the SignalP 3.0 algorithm

140 (http://www.cbs.dtu.dk/services/SignalP/) while the Twin-arginine (Tat-type) and the

141 lipoprotein signal peptides were determined with the TatP 1.0

142 (http://www.cbs.dtu.dk/services/TatP/) and the $\quad$ LipoP $\quad 1.0$

143 (http://www.cbs.dtu.dk/services/LipoP/) algorithms respectively. TMHMM 2.0 algorithm was

144 used to predict transmembrane domains (http://www.cbs.dtu.dk/services/TMHMM/). The

145 different softwares cited below are all available from www.expasy.org.

146

147 2. 8. Western blot analysis

148 Two SDS PAGE gels were run in parallel. One was used for identification and the other

149 for immunoblot. $150 \mu \mathrm{g}$ of proteins were loaded in each well to compare each culture

150 condition. Proteins resolved by SDS PAGE were electroblotted onto nitrocellulose

151 membranes (Amersham Biosciences, Orsay, France) with Towbin transfer buffer using a

152 Trans-Blot $^{\circledR}$ SD semi-dry transfer cell (Bio-Rad Laboratories) at $15 \mathrm{~V}$ for $40 \mathrm{~min}$. Blotted

153 membranes were blocked with $5 \%(\mathrm{w} / \mathrm{v})$ skimmed milk powder in TBS buffer (10 mM Tris,

$1540.2 \mathrm{M} \mathrm{NaCl}, 0.05 \%(\mathrm{v} / \mathrm{v})$ Tween 20$)$ overnight at $4^{\circ} \mathrm{C}$ and incubated with pooled sera from

155 nine foals that had died of rhodococcosis at 1:200 dilution in blocking solution for $1 \mathrm{~h}$ at

$15637^{\circ} \mathrm{C}$. Membranes were then washed three times for 15 min each with TBS buffer. They were

157 incubated with rabbit anti-horse $\mathrm{IgG}$, conjugated to alkaline phosphatase, at 1:5000 dilution

158 (Bethyl Laboratories, Montgomery, TX, USA) for $1 \mathrm{~h}$ at $37^{\circ} \mathrm{C}$ and washed as described

159 above. Antigen-antibody reactions were developed with AP Conjugate Substrate kit (Bio-Rad

160 Laboratories) according to the manufacturer.

161

162 2. 9. Cloning and expression of twelve genes 
The primers and vectors used for PCR amplification and cloning are listed (Table 1). The

164 primers were designed on the available $R$. equi genome sequence. PCR products obtained with $R$. equi ATCC 33701 DNA were cloned into pQE30 (Qiagen) or pET-30 Ek/LIC vector (Novagen) to obtain recombinant plasmids following the recommendations of the supplier (Table 1). Recombinant $\mathrm{pQE} 30$ vectors were transformed into E. coli M15 while recombinant pET-30 Ek/LIC vectors were transformed into E. coli BL21(DE3). The presence of appropriate insert was confirmed by sequencing.

To assess expression of the cloned genes, recombinant E. coli M15 or E. coli BL21(DE3) were grown overnight at $37^{\circ} \mathrm{C}$ in $10 \mathrm{ml}$ of $\mathrm{LB}$ medium supplemented with $30 \mu \mathrm{g} / \mathrm{ml}$ of kanamycin (Sigma) for the two E. coli strains and $100 \mu \mathrm{g} / \mathrm{ml}$ of ampicillin (Sigma) for E. coli M15 only. One $\mathrm{ml}$ of the bacterial suspension was then subinoculated into $100 \mathrm{ml}$ of fresh LB medium and the bacteria were allowed to grow at $37^{\circ} \mathrm{C}$ until the optical density of the medium at $600 \mathrm{~nm}$ reached 0.6 . Thereafter, the expression of the cloned genes was induced by addition of IPTG (ABgene, Courtaboeuf, France) to a final concentration of $1 \mathrm{mM}$. After a further $3 \mathrm{~h}$ incubation at $37^{\circ} \mathrm{C}$, the bacterial cells were collected by centrifugation for $10 \mathrm{~min}$ at 5,000 g. The cell lysis was performed by incubation for $1 \mathrm{~h}$ with a lysis buffer containing $100 \mathrm{mM} \mathrm{NaH} \mathrm{PO}_{4}$ (Merck), $10 \mathrm{mM}$ Tris base and $8 \mathrm{M}$ urea (Eurobio). The cell debris were removed by centrifugation at $10,000 \mathrm{~g}$ for $10 \mathrm{~min}$. Supernatants were used for Western blot analysis.

182

\section{3. Results}

\section{1. Analysis of secreted proteins by SDS PAGE}

Secreted proteins were extracted from the supernatant of cultures of $R$. equi grown in the poor protein containing LB medium in order to limit contamination by medium derived polypeptides. Secreted proteins obtained at $30^{\circ} \mathrm{C}$ or $37^{\circ} \mathrm{C}$ and at mid-exponential or early- 
188 stationary phase were analyzed by SDS PAGE (Fig. 1). According to standard marker

189 proteins, secreted polypeptides had molecular weight ranging from 7 to $100 \mathrm{kDa}$. At $30^{\circ} \mathrm{C}$, the

190 migration patterns of secreted proteins did not appear to have significant differences

191 depending on the growth phase and at least 21 distinct bands were detected. At $37^{\circ} \mathrm{C}$, three

192 additional bands around $29 \mathrm{kDa}$ (bands No. 17 to 19) were present in supernatants harvested

193 in early-stationary phase compared to mid-exponential phase. Furthermore, regardless of the

194 growth phase, six additional bands between 7 and $20 \mathrm{kDa}$ (bands No. 23 to 27 and 30) were

195 detected in supernatants from cultures grown at $37^{\circ} \mathrm{C}$ compared to $30^{\circ} \mathrm{C}$. Finally, several

196 intensively Coomassie-stained bands were observed: four bands (No. 1, 3, 6 and 15) in all

197 tested supernatants and three additional bands (No. 25 to 27) expressed in supernatants

198 harvested at $37^{\circ} \mathrm{C}$.

\section{2. Proteins identification}

20130 bands were cut out of gels (bands No. 1 to 30, Fig. 1), subjected to in-gel trypsin

202 digestion and analyzed by LC-ESI tandem mass spectrometry. In parallel, the secretome of $R$.

203 equi was also analyzed without previous electrophoretic separation by injecting a

204 trypsinolysed crude preparation of secreted proteins into LC-ESI tandem mass spectrometer

205 (see Materials and Methods for details). These two approaches led to the identification of 44

206 and 16 proteins, respectively (Table 2). The method without previous electrophoretic

207 separation allowed us to identify fewer secreted proteins than the other method but led to the

208 rapid identification of dominant proteins present in the secretome. Since we found twelve

209 identical proteins in both methods, a total of 48 proteins was finally identified. All identified

210 proteins were encoded by the chromosome except for the Vap proteins. Because of the non-

211 annotated genome sequence of $R$. equi, homologous proteins were identified using BLASTP

212 program and the homology with the first hit was indicated for each protein (Table 2). Six 
213 proteins arbitrarily named proteins X1 to X6 did not share any similarity with proteins from

214 other organisms. For the majority of the proteins $(73 \%)$, a potential function could be 215 assigned due to the presence of conserved domains detected by NCBI CDD algorithm. All 216 proteins identified in the culture filtrate could be classified into several major functional 217 categories: pathogenicity (ChoE, VapA), stress adaptation (alkyl hydroperoxide reductase, 218 catalase, Cpn10, GroEL, CspA, probable Stage II sporulation protein), export (MspA), cell 219 wall biosynthesis (four probable mycolyl transferases arbitrarily named 1 to 4 , $\mathrm{N}$-acetyl 220 muramoyl-L-alanine amidase), reactivation of bacteria in stationary phase (probable 221 resuscitation promoting factor), energy metabolism (dihydrolipoyl dehydrogenase, 222 phosphomannomutase), fatty acid metabolism (lipid-transfer protein), general cell processes 223 and hypothetical proteins without known function.

224 The molecular weights of most proteins detected in SDS PAGE were consistent with the 225 theoretical values (Table 2). However, several proteins displayed a significantly higher mass than expected. Six proteins were represented by several isoforms of different molecular weights. The cholesterol oxidase ChoE was presented in six, VapD in four, VapA and mycolyl transferase 3 (MT3) in three and elongation factor Tu and protein X4 in two different fractions. By taking into account the growth conditions, the three additional bands around 29 kDa (No. 17 to 19, Fig. 1) in supernatants harvested in early-stationary phase compared to

231 mid-exponential phase at $37^{\circ} \mathrm{C}$ were composed of one isoform of mycolyl transferase 3 , four 232 hypothetical proteins and a probable protease from Rhodococcus sp. strain RHA1. Moreover, 233 the six additional bands between 7 and $20 \mathrm{kDa}$ (No. 23 to 27 and 30, Fig. 1) in supernatants 234 from cultures grown at $37^{\circ} \mathrm{C}$ compared to $30^{\circ} \mathrm{C}$ contained three isoforms of VapA, two 235 isoforms of VapD, protein X1 and probable mycolyl transferase 3 (no result was obtained for 236 the band No. 26). The unfractionated protein extract analysis revealed that VapA and VapD 237 were detected only at $37^{\circ} \mathrm{C}$. 
Concerning the most intensively Coomassie-stained bands, cholesterol oxidase and probable mycolyl transferase 1 (No. 1, 3, 6 and 15, Fig. 1) were present in all tested supernatants whereas protein X1, VapA and VapD (No. 25 to 27, Fig. 1) were only expressed

241 in supernatants harvested at $37^{\circ} \mathrm{C}$. Cholesterol oxidase, VapA and VapD were also identified 242 among the unfractionated protein extract directly analyzed by mass spectrometry.

\subsection{Protein structure and localization}

SignalP 3.0 algorithm revealed the presence of cleavage site for signal peptidases (SPases) for 24 out of the 48 identified proteins (Table 3), suggesting that these are secreted proteins.

247 Three proteins were recognized by the TatP 1.0 algorithm as harboring a twin-arginine (Tat) 248 signal peptide. The consensus sequence recognized by this algorithm is RRX[FGAVML][LITMVF]. It contains the two invariant arginine residues and variable amino-acids indicated between parentheses or by the $\mathrm{X}$ letter. Nine additional proteins contained a complete or incomplete Tat motif with at least the two arginines in their signal peptide but they were not recognized by the TatP 1.0 algorithm. The other 12 proteins contained a signal peptide specific for the general protein secretion (Sec) pathway (Table 3). In our study, the Sec and Tat signal peptides had a length varying from 26 to 63 amino acids. Both signal peptides were composed of three domains, a positively charged N-terminal domain (n-region), a hydrophobic domain (h-region) and a hydrophilic C-terminal domain (cregion) usually carrying the consensus $\mathrm{AXA}$ at position -1 to -3 relative to the cleavage site

258 for SPases I (Tjalsma et al., 2000). This consensus was observed for twenty out of the 24 signal peptides (Table 3 ). If the 24 signal peptides were taken into consideration, the general consensus sequence at position -3 to -1 relative to the SPases I cleavage site was (A/V)-X-

$261(\mathrm{~A} / \mathrm{K} / \mathrm{T})$. The consensus sequence $\mathrm{L}-(\mathrm{A} / \mathrm{S})-(\mathrm{A} / \mathrm{G})-\mathrm{C}$ at position -3 to +1 relative to the SPases 
262 II cleavage site had never been found, suggesting the absence of lipoprotein signal peptides

263 (Table 3). At last, 24 proteins contained no obvious signal sequence.

264 According to the TMHMM 2.0 algorithm, we could predict a putative membrane

265 localization for two proteins. The polypeptide homologous to the hypothetical protein

266 RHA1_ro05477 contained, in addition to a signal peptide, two transmembrane domains at

267 central position. The polypeptide homologous to the hypothetical protein RHA1_ro03156,

268 which did not possess a signal peptide, contained a single transmembrane domain localized at

269 the N-terminus (Table 3). These two proteins may correspond to a membrane protein and a

270 surface protein, respectively. Furthermore, according to the NCBI CDD algorithm, the

271 probable mycolyl transferase 1 contained at its C-terminus three LGFP tandem repeats, which

272 may be involved in anchoring the protein to the cell wall.

273

\section{4. Antigenic profiles of $R$. equi secretome}

Antigenic profiles were explored by immunoblot performed with pooled sera from nine $R$. equi infected foals (Fig. 2). No band was detected in the control medium. Moreover, Western blot control experiments using antisera from healthy foals did not reveal any immunogenic protein (data not shown). Independent of growth conditions, immunogenic proteins were present in four regions with molecular weights about 99, 54, 29 and $20 \mathrm{kDa}$, respectively. A protein band of a monodimensional gel may harbor more than one polypeptide and probably not all of them would correspond to imunoreactive proteins. Analysis of the four bands by mass spectrometry revealed the presence of the following proteins: cholesterol oxidase, catalase, hypothetical proteins RHA1_ro06188, RHA1_ro03156, RHA1_ro05216, RHA1_ro05669, probable protease, probable secreted protein named PSP, VapA, VapD, probable mycolyl transferases 3 and 1 . In order to test which of them reacts actually with the 
287 Western blot analysis using the same pooled horse sera as in Fig. 2 (Fig. 3B). No E. coli

288 immunoreactive proteins were observed in the negative controls with empty pQE30 and pET-

28930 vectors. In contrast, the serum reacted strongly with the PSP and the cholesterol oxidase.

290 The proteins VapA, VapD and the probable mycolyl transferase 1 were less immunoreactive

291 and the serum reacted only weakly with the proteins homologous to the hypothetical proteins

292 RHA1_ro06188 and RHA1_ro03156. The other recombinant proteins did not react with the 293 serum.

294

295

\section{Discussion}

In order to characterize new $R$. equi candidate antigens associated with rhodococcosis among secreted proteins, we used a proteomic approach combined with serum profiling by using sera from foals that had died of rhodococcosis. This approach enabled identification of 48 proteins released by the $R$. equi ATCC 33701 strain during growth. As expected, 24

300 polypeptides contained a signal peptide sequence required for their translocation across the cytoplasmic membrane via the Sec-pathway (Keyzer et al., 2003) or the Tat-pathway (Lee et al., 2006), the two most important secretion systems distributed in all bacterial genera. Among them, half the proteins were predicted to possess a potential Tat signal peptide, suggesting that the Tat pathway could be as significant as the Sec pathway in $R$. equi. In contrast to the latter, the former pathway is involved in the secretion of exclusively folded proteins and protein translocation has no requirement for ATP as an energy source but relies solely on the proton motive force. It is interesting to note that all proteins identified in the most intensively Coomassie-stained bands contained a Sec signal peptide (VapA and VapD) or a Tat signal peptide (cholesterol oxidase, protein X1, mycolyl transferases 1 and 3).

310 The majority of the 24 remaining proteins without identifiable signal peptides contained

311 proteins usually considered as strictly cytoplasmic and their presence in the secretome 
312 requires further investigation. Abundant cytoplasmic proteins are often found in the secretome

313 of other pathogens such as M. tuberculosis (Malen et al., 2007), Listeria monocytogenes

314 (Trost et al., 2005) or Staphylococcus aureus (Sibbald et al., 2006) and extracellular roles

315 have been suggested. For example, the cytoplasmic elongation factor Tu (EF-Tu) is described

316 as a surface protein, which may exhibit an unexpected and novel function, the adhesion of

317 bacteria to host tissue (Dallo et al., 2002). A similar activity has been reported for GroEL in

318 several pathogens (Bergonzelli et al., 2006). Two R. equi groEL2- based DNA vaccines were

319 used in immunization of mice and were found to elicit a predominantly Th1 biased immune

320 response (Phumoonna et al., 2008; Vanniasinkam et al., 2004). But their protective efficacy

321 against $R$. equi infection was not demonstrated. The mode of secretion for these proteins is

322 unknown but they can be released by cell lysis or by hitherto unknown non-classical secretion

323 pathways or signal peptide-independent pathways (Bendtsen et al., 2005). Such non-classical

324 systems have been reported in M. tuberculosis and L. monocytogenes for the export of

325 virulence factors without signal peptide (Bendtsen et al., 2005). For many years, it has been

326 known that $M$. tuberculosis secretes antigenic proteins without apparent signal peptide such as

327 ESAT-6 (early secretory antigenic target) (Bendtsen et al., 2005).

328 The cholesterol oxidase was, under all conditions tested, the major secreted protein of $R$.

329 equi ATCC 33701. Despite its membranolytic activity, this enzyme was demonstrated not to

330 be an important virulence factor in the natural host (Pei et al., 2006). It may be important in

331 providing carbon sources for $R$. equi inside macrophages, as they are for other intracellular

332 bacteria such as Mycobacterium avium and M. tuberculosis. The variants or isoforms of 333 cholesterol oxidase may be attributed to biologically important post-translational

334 modifications, ranging from chemical modifications, such as glycosylations for isoforms of

335 higher molecular weight than the calculated one, to proteolytic cleavage for polypeptides with

336 molecular weight significantly lesser than the expected one. VapA, an atypical lipoprotein, is 
another virulence factor involved in the intracellular growth in macrophages and identified

338 among secreted proteins in our experimental conditions, contrary to previous studies which detected VapA in the cell pellet only (Byrne et al., 2001; Kohler et al., 2003). Its presence in the supernatant can be explained by the fact that lipoproteins are vulnerable to proteolytic

341 cleavage relatively close to the $\mathrm{N}$-terminal cysteine and are consequently released as soluble

342 protein in the culture filtrate (Malen et al., 2007). Moreover, it has been suggested that some

343 lipoproteins may be alternatively processed by signal peptidase I or II, and this mechanism

344 may explain their dual localization in the extracellular environment or as lipoproteins in the

345 cell wall (Malen et al., 2007). In our work, VapA was observed in three isoforms, in

346 accordance with the study of Tan et al. (1995). Indeed, in that work, the polypeptides isolated

347 from the $18-22 \mathrm{kDa}$ and $17.5 \mathrm{kDa}$ fractions were hydrophobic and lipid modified whereas the

348 15-kDa protein did not show this modification. VapD was detected in four isoforms which

349 correspond most probably to degradation products. VapA and VapD were observed only at

$35037^{\circ} \mathrm{C}$ in our study which is in accordance with previous findings (Byrne et al., 2001).

351 Some proteins identified in the present study were predicted to be involved in the cell wall biosynthesis. Indeed, four out of at least $13 R$. equi probable mycolyl tranferases predicted by genome analysis (Sydor et al., 2007) were detected in our study. These four enzymes were homologous to the mycobacterial antigen 85 complex (Ag85 complex), major secretion products of M. tuberculosis (Content et al., 1991; Wiker and Harboe, 1992). This Ag85 complex is made of three mycolyl transferases ( $\mathrm{FbpA}, \mathrm{FbpB}$ and $\mathrm{FbpC}$ ), pivotal for the synthesis of the mycolic acid layer in the cell wall (Belisle et al., 1997). The probable mycolyl transferases 1 and 2 are encoded by the gene $f b p A$ (Sydor et al., 2007) and $f b p B$ (Pei et al., 2007) of $R$. equi, respectively. In $R$. equi, FbpA could be involved in capsule anchorage since 
most abundant proteins of the secretome regardless of growth conditions (Band No 3, Fig 1).

363 It should be noted that recent virulence studies in a murine model showed that both FbpA and

364 FbpB might not be involved in R. equi pathogenesis (Pei et al., 2007; Sydor et al., 2007).

365 Immunological characterization of $R$. equi secreted proteins by sera from foals that had

366 died of rhodococcosis revealed antigenic reactivity with four 99, 54, 29 and $20 \mathrm{kDa}$

367 immunogenic regions, similar to the immunoblots obtained by Kohler et al. (2003). By using

368 recombinant proteins, we demonstrated that five proteins (VapA, VapD, cholesterol oxidase,

369 probable mycolyl transferase 1 and the PSP) were indeed involved in the immunogenicity of

370 these four regions. Contrary to previous studies which identified Vap proteins as strongly

371 immunoreactive proteins (Byrne et al., 2001; Kohler et al., 2003), the two most strongly

372 immunoreactive proteins detected in the present study were the cholesterol oxidase and the

373 PSP. Machang'u and Prescott (1991b) showed that antibodies against the cholesterol oxidase

374 associated to the phospholipase $\mathrm{C}$ of $R$. equi did not prevent foals from developing lung

375 abscesses following experimental infection. However, this result has to be examined by taking

376 into account the infective dose, the dose and the nature of antigens which correspond to a

377 combination of two proteins, the immunization and infection routes and the type of adjuvant.

378 Indeed, recent studies demonstrated that these various parameters may influence the

379 polarization of immune response which must be a cellular type response to confer protection

380 against $R$. equi infection (Lunn and Townsend, 2000). The strong immune response to the

381 PSP suggests that this protein was readily accessible to the immune system in vivo and

382 consequently supports the fact that it was actively secreted despite the lack of a signal peptide.

383 This protein needs to be further characterized. Finally, the latter protein, cholesterol oxidase

384 and VapA that has been shown highly immunogenic (Kohler et al., 2003) in foals and

385 protective in a murine model (Haghighi and Prescott, 2005) may represent promising antigen

386 candidates for the vaccine development against equine rhodococcosis. 


\section{Conclusion}

389 To our knowledge, this is the first report of a comprehensive proteomic analysis of

390 secreted proteins of $R$. equi. The associated immunological characterization allowed us to

391 identify several proteins recognized by the host immune system, including a novel strongly

392 immunoreactive protein without known function. Studies to examine their imunoprotective

393 potential against $R$. equi infections are in progress.

394

395 Acknowledgements

396 This research was supported by grants from the Région Basse-Normandie, Haras

397 Nationaux and ADREF (Association pour le Développement de la Recherche Equine en 398 France).

399 We thank Doctor J. Cauchard (AFSSA Dozulé, France) for providing sera from nine foals 400 that had died of rhodococcosis. 
402

403

404

405

406

407

408

409

410

411

412

413

414

415

416

417

418

419

420

421

422

423

424

425

426

427

428

429

430

431

432

433

434

435

436

437

438

439

440

441

442

443

444

445

446

447

Belisle, J.T., Vissa, V.D., Sievert, T., Takayama, K., Brennan, P.J., Besra, G.S., 1997. Role of the major antigen of Mycobacterium tuberculosis in cell wall biogenesis. Science 276, $1420-1422$.

Bendtsen, J.D., Kiemer, L., Fausboll, A., Brunak, S., 2005. Non-classical protein secretion in bacteria. BMC Microbiol. 58, 1-13.

Bergonzelli, G.E., Granato, D., Pridmore, R.D., Marvin-Guy, L.F., Donnicola, D., CorthesyTheulaz, I.E., 2006. GroEL of Lactobacillus johnsonii La1 (NCC 533) is cell surface associated: potential role in interactions with the host and the gastric pathogen Helicobacter pylori. Infect. Immun. 74, 425-434.

Byrne, B.A., Prescott, J.F., Palmer, G.H., Takai, S., Nicholson, V.M., Alperin, D.C., Hines, S.A., 2001. Virulence plasmid of Rhodococcus equi contains inducible gene family encoding secreted proteins. Infect. Immun. 69, 650-656.

Content, J., de la Cuvellerie, A., De Wit, L., Vincent-Levy-Frebault, V., Ooms, J., De Bruyn, J., 1991. The genes coding for the antigen 85 complexes of Mycobacterium tuberculosis and Mycobacterium bovis BCG are members of a gene family: cloning, sequence determination, and genomic organization of the gene coding for antigen 85C of M. tuberculosis. Infect. Immun. 59, 3205-3212.

Dallo, S.F., Kannan, T.R., Blaylock, M.W., Baseman, J.B., 2002. Elongation factor Tu and E1 beta subunit of pyruvate dehydrogenase complex act as fibronectin binding proteins in Mycoplasma pneumoniae. Mol. Microbiol. 46, 1041-1051.

Giguère, S., Hondalus, M.K., Yager, J.A., Darrah, P., Mosser, D.M., Prescott, J.F., 1999. Role of the 85-kilobase plasmid and plasmid-encoded virulence-associated protein $\mathrm{A}$ in intracellular survival and virulence of Rhodococcus equi. Infect. Immun. 67, 35483557.

Haghighi, H.R., Prescott, J.F., 2005. Assessment in mice of vapA-DNA vaccination against Rhodococcus equi infection. Vet. Immunol. Immunopathol. 104, 215-225.

Jain, S., Bloom, B.R., Hondalus, M.K., 2003. Deletion of vapA encoding Virulence Associated Protein A attenuates the intracellular actinomycete Rhodococcus equi. Mol. Microbiol. 50, 115-128.

Kaufmann, S.H., Hess, J., 1999. Impact of intracellular location of and antigen display by intracellular bacteria: implications for vaccine development. Immunol. Lett. 65, 81-84.

de Keyzer, J., van der Does, C., Driessen, A.J., 2003. The bacterial translocase: a dynamic protein channel complex. Cell. Mol. Life Sci. 60, 2034-2052.

Kohler, A.K., Stone, D.M., Hines, M.T., Byrne, B.A., Alperin, D.C., Norton, L.K., Hines, S.A., 2003. Rhodococcus equi secreted antigens are immunogenic and stimulate a type 1 recall response in the lungs of horses immune to $R$. equi infection. Infect. Immun. 71, 6329-6337.

Lee, P.A., Tullman-Ercek, D., Georgiou, G., 2006. The bacterial twin-arginine translocation pathway. Annu. Rev. Microbiol. 60, 373-395.

Lowry, O.H., Rosebrough, N.J., Farr, A.L., Randall, R.J., 1951. Protein measurement with the Folin phenol reagent. J. Biol. Chem. 193, 265-275.

Lunn, D.P., Townsend, H.G., 2000. Equine vaccination. Vet. Clin. North Am. Equine Pract. $16,199-226$.

Machang'u, R.S., Prescott, J.F., 1991a. Purification and properties of cholesterol oxidase and choline phosphohydrolase from Rhodococcus equi. Can. J. Vet. Res. 55, 332-340. 
Machang'u, R.S., Prescott, J.F., 1991b. Role of antibody to extracellular proteins of Rhodococcus equi in protection against $R$. equi pneumonia in foals. Vet. Microbiol. 26, 323-333.

Malen, H., Berven, F.S., Fladmark, K.E., Wiker, H.G., 2007. Comprehensive analysis of exported proteins from Mycobacterium tuberculosis H37Rv. Proteomics 7, 17021718.

Muscatello, G., Leadon, D.P., Klayt, M., Ocampo-Sosa, A., Lewis, D.A., Fogarty, U., Buckley, T., Gilkerson, J.R., Meijer, W.G., Vazquez-Boland, J.A., 2007. Rhodococcus equi infection in foals: the science of 'rattles'. Equine Vet. J. 39, 470-478.

Pei, Y., Dupont, C., Sydor, T., Haas, A., Prescott, J.F., 2006. Cholesterol oxidase (ChoE) is not important in the virulence of Rhodococcus equi. Vet. Microbiol. 118, 240-246.

Pei, Y., Parreira, V., Nicholson, V.M., Prescott, J.F., 2007. Mutation and virulence assessment of chromosomal genes of Rhodococcus equi 103. Can. J. Vet. Res. 71, 1-7.

Phumoonna, T., Barton, M.D., Vanniasinkam, T., Heuzenroeder, M.W., 2008. Chimeric vapA/groEL2 DNA vaccines enhance clearance of Rhodococcus equi in aerosol challenged C3H/He mice. Vaccine 26, 2457-2465.

Sauvageot, N., Pichereau, V., Louarme, L., Hartke, A., Auffray, Y., Laplace, J.M., 2002. Purification, characterization and subunits identification of the diol dehydratase of Lactobacillus collinoides. Eur. J. Biochem. 269, 5731-5737.

Sibbald, M.J., Ziebandt, A.K., Engelmann, S., Hecker, M., de Jong, A., Harmsen, H.J., Raangs, G.C., Stokroos, I., Arends, J.P., Dubois, J.Y., van Dijl, J.M., 2006. Mapping the pathways to staphylococcal pathogenesis by comparative secretomics. Microbiol. Mol. Biol. Rev. 70, 755-788.

Sydor, T., von Bargen, K., Becken, U., Spuerck, S., Nicholson, V.M., Prescott, J.F., Haas, A., 2007. A mycolyl transferase mutant of Rhodococcus equi lacking capsule integrity is fully virulent. Vet. Microbiol. 128, 327-341.

Takai, S., Hines, S.A., Sekizaki, T., Nicholson, V.M., Alperin, D.A., Osaki, M., Takamatsu, D., Nakamura, M., Suzuki, K., Ogino, N., Kakuda, T., Dan, H., Prescott, J.F., 2000. DNA sequence and comparison of virulence plasmids from Rhodococcus equi ATCC 33701 and 103. Infect. Immun. 68, 6840-6847.

Takai, S., Koike, K., Ohbushi, S., Izumi, C., Tsubaki, S., 1991a. Identification of 15- to 17kilodalton antigens associated with virulent Rhodococcus equi. J. Clin. Microbiol. 29, 439-443.

Takai, S., Sekizaki, T., Ozawa, T., Sugawara, T., Watanabe, Y., Tsubaki, S., 1991b. Association between a large plasmid and 15- to 17-kilodalton antigens in virulent Rhodococcus equi. Infect. Immun. 59, 4056-4060.

Tan, C., Prescott, J.F., Patterson, M.C., Nicholson, V.M., 1995. Molecular characterization of a lipid-modified virulence-associated protein of Rhodococcus equi and its potential in protective immunity. Can. J. Vet. Res. 59, 51-59.

Tjalsma, H., Bolhuis, A., Jongbloed, J.D., Bron, S., van Dijl, J.M., 2000. Signal peptidedependent protein transport in Bacillus subtilis: a genome-based survey of the secretome. Microbiol. Mol. Biol. Rev. 64, 515-547.

Trost, M., Wehmhoner, D., Karst, U., Dieterich, G., Wehland, J., Jansch, L., 2005. Comparative proteome analysis of secretory proteins from pathogenic and nonpathogenic Listeria species. Proteomics 5, 1544-1557.

Vanniasinkam, T., Barton, M.D., Heuzenroeder, M.W., 2004. The immunogenicity of Rhodococcus equi GroEL2-based vaccines in a murine model. Vet. Immunol. Immunopathol. 98, 91-100.

Wiker, H.G., Harboe, M., 1992. The antigen 85 complex: a major secretion product of Mycobacterium tuberculosis. Microbiol. Rev. 56, 648-661. 
499 Fig. 1. Separation of secreted proteins from $R$. equi by SDS-PAGE. Proteins extracted from R. equi ATCC 33701 grown in LB medium at $30^{\circ} \mathrm{C}$ (lanes 2,3 ) or $37^{\circ} \mathrm{C}$ (lanes 4,5 ) and at the mid-exponential (lanes 2, 4) or the early-stationary (lanes 3, 5) growth phase. Lane 1 contains proteins extracted from non inoculated LB medium (negative control). All lanes are loaded with $150 \mu \mathrm{g}$ of protein. The spots 1 to 30 indicate bands analyzed by LC ESI MS/MS. The numbers on the left indicate molecular masses (in kilodaltons).

Fig. 2. Detection of immunogenic proteins in the culture supernatant of $R$. equi. Immunoblot of secreted proteins from $R$. equi ATCC 33701 was probed with pooled sera from nine foals that had died of rhodococcosis. Lanes were loaded with $150 \mu \mathrm{g}$ of secreted proteins $R$. equi ATCC 33701 as follows: lane 1, non inoculated LB medium (negative control medium); lane 2, $30^{\circ} \mathrm{C}$ mid-exponential phase; lane $3,30^{\circ} \mathrm{C}$ early-stationary phase; lane $4,37^{\circ} \mathrm{C}$ midexponential phase; lane $5,37^{\circ} \mathrm{C}$ stationary phase. The numbers on the left indicate molecular masses (in kilodaltons).

513

514 Fig. 3. Overexpression and Western blot analysis of recombinant $R$. equi proteins. A) SDS-

515 PAGE of lysates of E. coli M15 or E. coli BL21(DE3) expressing the recombinant proteins.

516 Lane 1, molecular mass marker; lane 2, empty pQE30 vector; lane 3, E. coli lysate containing

517 recombinant cholesterol oxidase; lane 4, E. coli lysate containing recombinant catalase; Lane

518 5, empty pET-30 vector; Lanes 6 to 15, the following recombinant proteins: hypothetical 519 proteins RHA1_ro06188, RHA1_ro03156, RHA1_ro05216, RHA1_ro05669, probable 520 protease, PSP (probable secreted protein), VapA, VapD, probable mycolyl transferase 3, 521 probable mycolyl transferase 1 . B) Western blot showing reactivity of sera with the twelve 522 recombinant proteins. Sera were obtained from foals that had died of rhodococcosis. 
Fig. 1

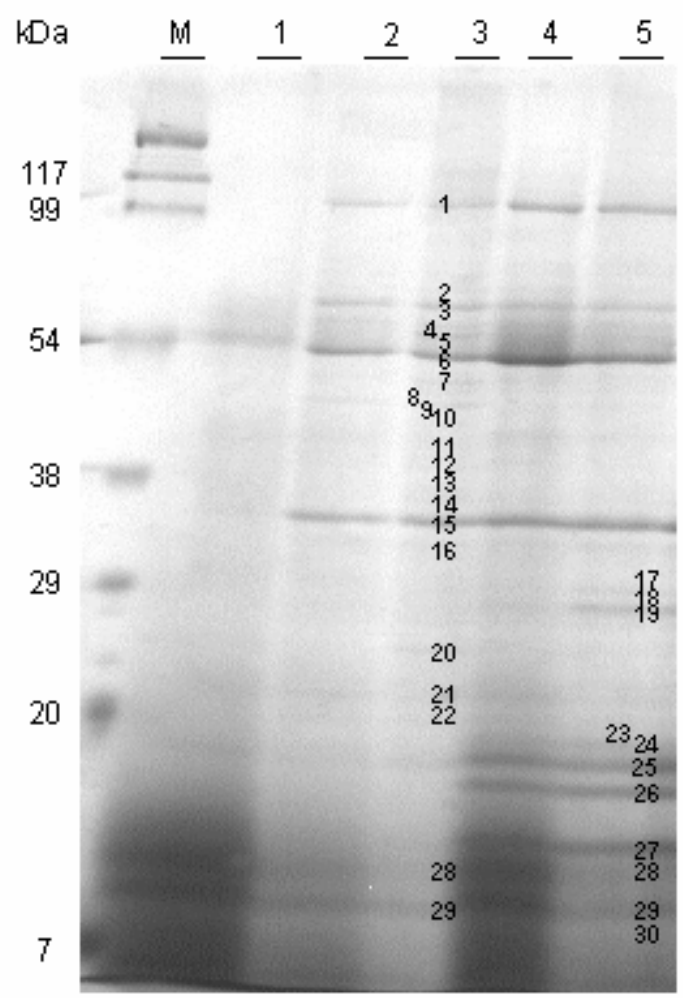


Fig. 2

$\mathrm{KDa} \quad \mathrm{M} \quad 1 \quad 2 \quad 3 \quad 4 \quad 5$

117

54

38

29

20

7 
Fig. 3

A)

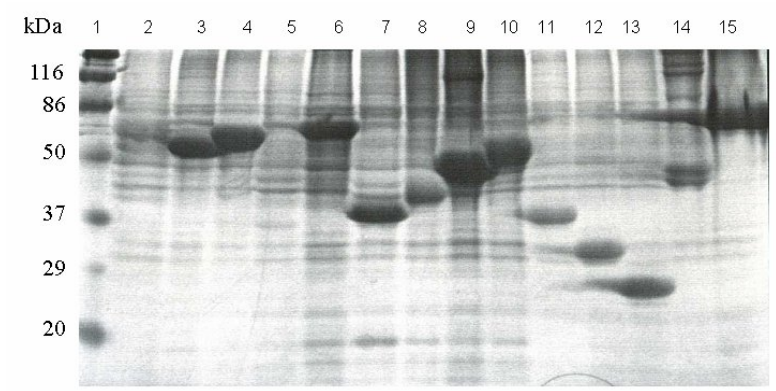

B)

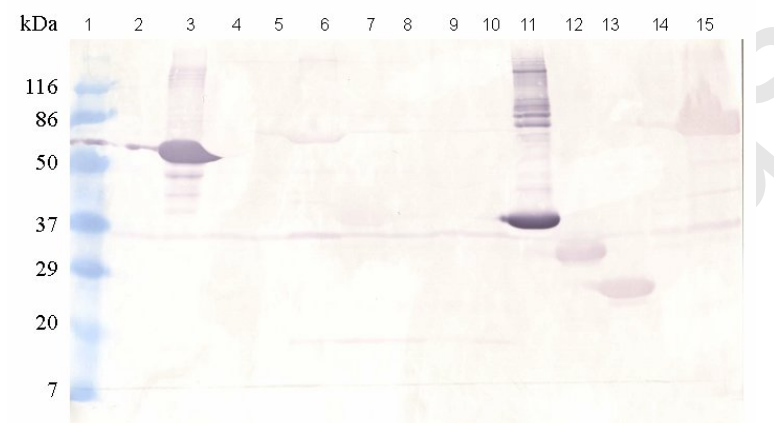


Table 1. Primers and vectors used in gene cloning

\begin{tabular}{|c|c|c|}
\hline Gene of & Primers $^{a}$ & Vector \\
\hline catalase & 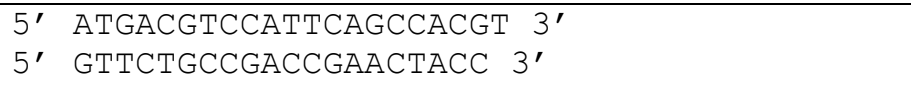 & pQE30 \\
\hline ChoE & $\begin{array}{l}5^{\prime} \text { TCCGCCTCCGGAGCTCCCAGCC } 3^{\prime} \\
5^{\prime} \text { TCTCATAAGCTTCGACGCGT } 3^{\prime}\end{array}$ & pQE30 \\
\hline hypothetical protein RHA1_ro03156 & $\begin{array}{ll}5^{\prime} & \text { GACGACGACAAGATCCAGCAGGAGAACACCTC } 3^{\prime} \\
5^{\prime} & \text { GAGGAGAAGCCCGGTCTAGCCGTAACTGACGACGAC }\end{array}$ & pET-30 Ek/LIC \\
\hline hypothetical protein RHA1_ro05216 & $\begin{array}{ll}5^{\prime} & \text { GACGACGACAAGATCGTGGCTGCAATGACCTCC } \\
5^{\prime} & 3^{\prime} \\
\end{array}$ & pET-30 Ek/LIC \\
\hline hypothetical protein RHA1_ro05669 & $\begin{array}{lll}5^{\prime} & \text { GACGACGACAAGATCCAGCACAAGACGATCACACTC } & 3^{\prime} \\
5^{\prime} & \text { GAGGAGAAGCCCGGTTTACCGGAGACCCAACTTGCT } & 3^{\prime}\end{array}$ & $\mathrm{pET}-30 \mathrm{Ek} / \mathrm{LIC}$ \\
\hline hypothetical protein RHA1_ro06188 & $\begin{array}{lll}5^{\prime} & \text { GACGACGACAAGATACCGCTGCCGGCGTCGAT } & 3^{\prime} \\
5^{\prime} & \text { GAGGAGAAGCCCGGTCTAGCGCAGTGTGGCGAG } & 3^{\prime}\end{array}$ & $\mathrm{pET}-30 \mathrm{Ek} / \mathrm{LIC}$ \\
\hline $\begin{array}{l}\text { probable antigen } 85 \text { protein precursor } \\
\text { (mycolyl transferase } 3 \text { ) }\end{array}$ & $\begin{array}{ll}5^{\prime} & \text { GACGACGACAAGATCTCGACGCCCGGCGCGACCGAC } \\
5^{\prime} & 3^{\prime} \\
\text { GAGGAGAAGCCCGGTCTACCGGGGAGTGCCCATG } & 3^{\prime}\end{array}$ & pET-30 Ek/LIC \\
\hline $\begin{array}{l}\text { probable antigen } 85 \text { complex protein } \\
\text { (mycolyl transferase } 1)\end{array}$ & $\begin{array}{lll}5^{\prime} & \text { GACGACGACAAGATGGCACAGTCCCTCGGCACCCCC } & 3^{\prime} \\
5^{\prime} & \text { GAGGAGAAGCCCGGTTCAGGCGATGGTCGCCTTTCC } & 3^{\prime}\end{array}$ & pET-30 Ek/LIC \\
\hline probable protease & $\begin{array}{ll}5^{\prime} & \text { GACGACGACAAGATCGAACCCGCCGCGTCGGGT } \\
5^{\prime} & 3^{\prime} \\
\text { GAGGAGAAGCCCGGTATTCACCGATGTCGGTCAGTG } & 3^{\prime}\end{array}$ & pET-30 Ek/LIC \\
\hline probable secreted protein (PSP) & $\begin{array}{ll}5^{\prime} & \text { GACGACGACAAGATTGGTGTGGCGGACGCGG } 3^{\prime} \\
5^{\prime} & \text { GAGGAGAAGCCCGGTCTACGACAGCTCCCATCC }\end{array}$ & pET-30 Ek/LIC \\
\hline VapA & $\begin{array}{lll}5^{\prime} & \text { GACGACGACAAGATGACCGTTCTTGATTCCGGTAGC } & 3^{\prime} \\
5^{\prime} & \text { GAGGAGAAGCCCGGTCTAGGCGTTGTGCCAGCTACC } & 3^{\prime}\end{array}$ & $\mathrm{pET}-30 \mathrm{Ek} / \mathrm{LIC}$ \\
\hline VapD & $\begin{array}{lll}5^{\prime} & \text { GACGACGACAAGATGCAGGAGCTAGCTGGCACCAAG } & 3^{\prime} \\
5^{\prime} & \text { GAGGAGAAGCCCGGTCTACTCCCACCCGCCAGTGCC } & 3^{\prime}\end{array}$ & pET-30 Ek/LIC \\
\hline
\end{tabular}

${ }^{\mathrm{a}}$ The underlined letters in primers are complementary extensions compatible to sequences in the pET-30 Ek/LIC cloning vector. 
Table 2. Identification of secreted proteins by mass spectrometry on SDS PAGE (bands noted by a number) or in unfractionated protein extract

\begin{tabular}{|c|c|c|c|c|c|c|c|c|}
\hline \multirow[b]{2}{*}{ Band No. ${ }^{a}$} & \multirow{2}{*}{$\begin{array}{c}\text { Sp } \\
\text { score } \\
\mathrm{b}\end{array}$} & \multicolumn{5}{|c|}{ Identified protein $^{\mathrm{c}}$} & \multirow[b]{2}{*}{$\begin{array}{l}\text { Observed } \\
\text { MW }(\mathrm{kDa})^{\mathrm{f}}\end{array}$} & \multirow[b]{2}{*}{$\begin{array}{l}\text { Theoretical } \\
\text { MW (kDa) }\end{array}$} \\
\hline & & Description & Bacteria $^{d}(\%$ Ic & lentity) & $\begin{array}{l}\text { NCBI Accession } \\
\text { No. }\end{array}$ & Protein domain $^{\mathrm{e}}$ & & \\
\hline 1 & 1442 & Cholesterol oxidase ChoE & R. equi 103 & $(100)$ & CAC44897 & $\begin{array}{l}\text { choline dehydrogenase / related } \\
\text { flavoproteins }\end{array}$ & 100 & 54.5 \\
\hline \multirow[t]{2}{*}{2} & 1627 & Cholesterol oxidase ChoE & R. equi 103 & $(100)$ & CAC44897 & $\begin{array}{l}\text { choline dehydrogenase / related } \\
\text { flavoproteins }\end{array}$ & 70 & 54.5 \\
\hline & 2009 & $30 \mathrm{~S}$ ribosomal protein & $R$. sp RHA1 & (95) & YP_118107 & $\begin{array}{l}\text { ribosomal protein S1 like RNA } \\
\text { binding domain }\end{array}$ & 70 & 54.0 \\
\hline 3 & 798 & $\begin{array}{l}\text { Probable antigen } 85 \text { complex protein } \\
\text { (mycolyl transferase } 1 \text { ) }\end{array}$ & $R$. sp RHA1 & (71) & YP_704140 & $\begin{array}{l}\text { putative esterase } \\
3 \text { LGFP repeat motifs }\end{array}$ & 65 & 62.8 \\
\hline 4 & & No result & & & & & 60 & \\
\hline \multirow[t]{3}{*}{5} & 1388 & Catalase & R. equi 103 & $(100)$ & AY779519.1 & catalase & 55 & 55.0 \\
\hline & 1058 & Cholesterol oxidase ChoE & R. equi 103 & $(100)$ & CAC44897 & $\begin{array}{l}\text { choline dehydrogenase / related } \\
\text { flavoproteins }\end{array}$ & 55 & 54.5 \\
\hline & 2104 & Hypothetical protein RHA1_ro06188 & $R$. sp RHA1 & (75) & YP_706123 & & 55 & 58.5 \\
\hline 6 & 1440 & Cholesterol oxidase $\mathrm{ChoE}$ & R. equi 103 & $(100)$ & CAC 44897 & $\begin{array}{l}\text { choline dehydrogenase / related } \\
\text { flavoproteins }\end{array}$ & 54 & 54.5 \\
\hline 7 & 676 & Elongation factor $\mathrm{Tu}$ & N. farcinica & (95) & YP 121291 & EF Tu family (II and III domains) & 50 & 43.5 \\
\hline 8 & 1007 & Elongation factor $\mathrm{Tu}$ & N. farcinica & (95) & YP 121291 & EF Tu family (II and III domains) & 48 & 43.5 \\
\hline \multirow[t]{4}{*}{9} & 922 & DNA-directed RNA polymerase $\alpha$-subunit & $R$. sp RHA1 & (98) & YP_706097 & $\begin{array}{l}\text { RNA polymerase Rbp3 / Rpb11 } \\
\text { dimerisation domain / RpoA insert } \\
\text { domain / } \alpha \text {-chain } C \text { terminal domain }\end{array}$ & 46 & 38.1 \\
\hline & 647 & Hypothetical protein RHA1_ro05154 & R. sp RHA1 & (77) & YP_705093 & & 46 & 21.0 \\
\hline & 1035 & Probable stage II sporulation protein & $R$. sp RHA1 & (51) & ABG95848 & stage II sporulation protein & 46 & 54.8 \\
\hline & 448 & Short-chain dehydrogenase/reductase & S. tropica & (67) & YP_001159019 & $\begin{array}{l}\text { short chain dehydrogenase / } 3 \\
\text { ketoacyl (acyl carrier protein) } \\
\text { reductase }\end{array}$ & 46 & 33.0 \\
\hline \multirow[t]{3}{*}{10} & 1004 & Cholesterol oxidase ChoE & R. equi 103 & $(100)$ & CAC44897 & $\begin{array}{l}\text { choline dehydrogenase / related } \\
\text { flavoproteins }\end{array}$ & 45 & 54.5 \\
\hline & 1056 & Hypothetical protein RHA1_ro01045 & $R$. sp RHA1 & (54) & YP_701030 & secretory lipase & 45 & 36.5 \\
\hline & 1795 & Hypothetical protein RHA1 ro04854 & $R$. sp RHA1 & $(60)$ & YP 704797 & cutinase & 45 & 39.0 \\
\hline \multirow[t]{5}{*}{11} & 715 & Alkyl hydroperoxide reductase & $R$. sp RHA1 & (87) & YP 703236 & peroxiredoxin family & 42 & 21.0 \\
\hline & 703 & Cell division initiation protein & $R$. sp RHA1 & (78) & YP_701065 & $\begin{array}{l}\text { DivIVA protein (cell division } \\
\text { initiation protein) }\end{array}$ & 42 & 31.0 \\
\hline & 714 & Probable thioesterase & $R$. sp RHA1 & (66) & YP 707177 & thioesterase protein & 42 & 17.0 \\
\hline & 957 & Not matched (protein X3) & 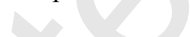 & & & & 42 & 24.0 \\
\hline & 645 & Short-chain dehydrogenase/reductase & S. tropica & (67) & YP_001159019 & $\begin{array}{l}\text { short chain dehydrogenase } / 3 \\
\text { ketoacyl (acyl carrier protein) } \\
\text { reductase }\end{array}$ & 42 & 33.0 \\
\hline \multirow[t]{2}{*}{12} & 1895 & Not matched (protein X4) & & & & & 40 & 37.0 \\
\hline & 1589 & Hypothetical protein RHA1_ro05704 & R. sp RHA1 & (64) & YP_705641 & glucose dehydrogenase & 40 & 37.2 \\
\hline \multirow[t]{3}{*}{13} & 1435 & $\begin{array}{l}\text { Probable antigen } 85 \text {-A precursor (mycolyl } \\
\text { transferase } 2 \text { ) }\end{array}$ & $R$. sp RHA1 & (43) & YP_704946 & putative esterase & 38 & 36.8 \\
\hline & 1906 & Not matched (protein X4) & & & & & 38 & 37.0 \\
\hline & 739 & Not matched (protein X5) & & & & & 38 & 37.0 \\
\hline \multirow[t]{2}{*}{14} & 701 & $\begin{array}{l}\text { Probable antigen } 85 \text { protein precursor } \\
\text { (mycolyl transferase } 3 \text { ) }\end{array}$ & $R$. sp RHA1 & (57) & YP_702108 & putative esterase & 37 & 34.5 \\
\hline & 816 & Hypothetical protein RHA1_ro04050 & $R$. sp RHA1 & (56) & YP_704005 & $\begin{array}{l}\mathrm{N} \text {-acetylmuramoyl-L-alanine } \\
\text { amidase domain }\end{array}$ & 37 & 68.0 \\
\hline 15 & 1678 & Cholesterol oxidase ChoE & R. equi 103 & $(100)$ & CAC44897 & $\begin{array}{l}\text { choline dehydrogenase / related } \\
\text { flavoproteins }\end{array}$ & 36 & 54.5 \\
\hline 16 & 450 & Amidase AmiC_1 & M. ulcerans & (49) & YP_906566 & amidase & 34 & 49.2 \\
\hline 17 & 701 & $\begin{array}{l}\text { Probable antigen } 85 \text { protein precursor } \\
\text { (mycolyl transferase } 3 \text { ) }\end{array}$ & R. $s p$ RHA1 & (57) & YP_702108 & putative esterase & 32 & 34.5 \\
\hline \multirow[t]{3}{*}{18} & 1672 & Hypothetical protein RHA1_ro03156 & $R$. sp RHA1 & (35) & YP_703117 & MspA (porin) & 29 & 30.2 \\
\hline & 1379 & Hypothetical protein RHA1_ro05216 & $R$. sp RHA1 & (66) & YP_705155 & & 29 & 30.2 \\
\hline & 1151 & Hypothetical protein RHA1 ro05669 & $R$. sp RHA1 & (67) & YP 705606 & transglycosylase-like domain & 29 & 36.0 \\
\hline \multirow[t]{2}{*}{19} & 1803 & Probable protease & $R$. sp RHA1 & (63) & YP_705835 & & 28 & 42.8 \\
\hline & 1124 & Probable secreted protein (PSP) & R. erythropolis & (46) & CAC 37046 & & 28 & 29.8 \\
\hline \multirow[t]{5}{*}{20} & 817 & $\begin{array}{l}\text { Probable mycolyl transferase (mycolyl } \\
\text { transferase 4) }\end{array}$ & $R$. sp RHA1 & (65) & YP_704013 & putative esterase & 25 & 33.0 \\
\hline & 1625 & Hypothetical protein $\mathrm{nfa} 45220$ & N. farcinica & (73) & YP_120737 & transglycosylase like domain & 25 & 8.0 \\
\hline & 2135 & Hypothetical protein RHA1_ro06358 & R. sp RHA1 & (69) & YP_706293 & & 25 & 8.0 \\
\hline & 840 & Cold shock protein A & $R$. sp RHA1 & (98) & YP_704299 & cold shock protein & 25 & 7.0 \\
\hline & 713 & Not matched (protein X6) & & & & & 25 & 53.3 \\
\hline 21 & 2579 & Not matched (protein X2) & & & & & 22 & 18.5 \\
\hline
\end{tabular}




$\begin{array}{lll} & 1033 & \text { Probable lipoprotein } \\ 22 & 881 & \text { Probable resuscitation-promoting factor } \\ 23 & 1543 & \text { Peptidyl-prolyl cis-trans isomerase } \\ 24 & 678 & \text { VapA (intracellular multiplication) } \\ 25 & 762 & \text { VapA (intracellular multiplication) } \\ & 793 & \text { VapA (intracellular multiplication) } \\ & 1604 & \text { Probable antigen } 85 \text { protein precursor } \\ & & \text { (mycolyl transferase 3) } \\ 26 & 666 & \text { Not matched (protein X1) } \\ 27 & 1045 & \text { VapD } \\ 28 & 1705 & \text { VapD } \\ & 1109 & \text { Hypothetical protein RHA1_ro05477 } \\ & 1055 & \text { Chaperonin Cpn10 } \\ 29 & 2117 & \text { VapD } \\ & 1607 & \text { Chaperonin Cpn10 } \\ & 581 & \text { Phosphomannomutase } \\ & & \\ & 930 & \text { Probable extracellular protein }\end{array}$

$\begin{array}{lll}\text { R. sp RHA1 } & (60) & \text { YP_704138 } \\ \text { R. sp RHA1 } & (67) & \text { YP_704901 } \\ \text { R. sp RHA1 } & (88) & \text { YP_704938 } \\ \text { R. equi } 103 & (100) & \text { BAB16621 } \\ \text { R. equi } 103 & (100) & \text { BAB16621 } \\ \text { R. equi } 103 & (100) & \text { BAB16621 } \\ \text { R. sp RHA1 } & (57) & \text { YP_702108 }\end{array}$

peptidase M23

22

18.0

transglycosylase like domain $\quad 22 \quad 17.5$

$\begin{array}{lll}\text { cyclophilin } & 20 & 22.0\end{array}$

R. equi virulence-associated protein $19 \quad 16.2$

$R$. equi virulence-associated protein $18 \quad 16.2$

R. equi virulence-associated protein $17 \quad 16.2$

$\begin{array}{lll}\text { putative esterase } & 17 & 34.5\end{array}$

17

11.0

R. equi $103 \quad$ (100) $\mathrm{BAB} 16624$

16

14.0

R. equi $103 \quad$ (100) BAB16624

$R$. sp RHA1 (37) YP_705415

M. sp JLS

R. equi 103

(94) $\mathrm{ZP}-01280279$
(94)

R. equi virulence-associated protein 14

R. equi virulence-associated protein 12

$\begin{array}{lll}\text { chaperonin Cpn } 10 & 12 & 18.5 \\ & 12 & 11.0\end{array}$

R. equi virulence-associated protein 10

M. sp JLS (94) ZP 01280279

chaperonin Cpn10 10

Phosphoglucomutase / 10

$R$. sp RHA1 (82) YP_706251

phosphomannomutase

48.6

$R$. sp RHA1 (37) YP_700670

R. equi 103

(100) BA- 16624

10

14.7 R. equi virulence-associated protein $9 \quad 14.0$

unfractionated 450 Catalase

protein extract

669 Chaperonin Cpn10

1898 Cholesterol oxidase ChoE

793 Cold shock protein A

895 Dihydrolipoyl dehydrogenase

545 Elongation factor $\mathrm{G}$

630 Elongation factor $\mathrm{Tu}$

1205 Chaperonin GroEL2

687 Hypothetical protein RHA1_ro04050

1268 Hypothetical protein RHA1_ro05477

1843 Hypothetical protein RHA1_ro06188

625 Probable nonspecific lipid-transfer protein

2337 Probable antigen 85 protein precursor (mycolyl transferase 3)

1339 Not matched (protein X2)

976 VapA

549 VapD
R. equi 103

M. sp JLS

R. equi 103

(94) ZP_01280279

(100) CAC44897

$R$. sp RHA1

$R$. sp RHA1

(98) YP_704299

(89) YP_706197

R. sp RHA1

$N$. farcinica

R. equi 103

(95) YP_701891

(94) YP_121291

(100) AAK95493

R. $s p$ RHA1

(56) YP_704005

R. sp RHA1

(37) YP_705415

$R$. sp RHA1

(75) YP_706123

(89) YP_704432

$R$. sp RHA1
$R$. sp RHA1

(57) YP 702108

R. equi 103

R. equi 103
(100) BAB16621

(100) BAB16624 catalase

55.0

chaperonin Cpn10

11.0

choline dehydrogenase / related

11.0
54.5

flavoproteins

cold shock protein

pyridine nucleotide-disulphide

7.2

oxidoreductase

EF G subfamily (II and IV domains) $\quad 76.9$

EF Tu family (II and III domains) 43.5

chaperonin GroEL

$\mathrm{N}$-acetylmuramoyl-L-alanine

amidase domain

43.5
56.5

68.0

21.1

58.5

thiolase domain

40.1

putative esterase

34.5

R. equi virulence-associated protein

16.2

R. equi virulence-associated protein

${ }^{\mathrm{a}}$ The band numbers were shown in Fig. 1 .

${ }^{\mathrm{b}} \mathrm{Sp}$ score given by Sequest for the most significant peptide $(\mathrm{Sp} \geq 450)$ found using a DNA database prepared from the non annotated genome sequence of $R$. equi 103 .

${ }^{\mathrm{c}}$ Best matching proteins with identities $\geq 35 \%$ were taken into consideration.

${ }^{\mathrm{d}}$ M. sp JLS, Mycobacterium sp JLS; M. ulcerans, Mycobacterium ulcerans; N. farcinica, Nocardia farcinica; R. sp RHA1,

Rhodococcus sp RHA1; R. erythropolis, Rhodococcus erythropolis; S. tropica, Salinispora tropica.

${ }^{\mathrm{e}}$ Protein domain as deduced from sequence analysis with the NCBI conserved domain algorithm.

${ }^{\mathrm{f}}$ Deduced from the gels.

${ }^{\mathrm{g}}$ The molecular weight of proteins without signal peptide. 
Table 3. Subcellular localization of proteins based on sequence analysis

\begin{tabular}{|c|c|c|c|}
\hline Identified proteins & $\begin{array}{c}\text { Export } \\
\text { pathway } \\
\text { a }\end{array}$ & Signal Peptide sequence (SP) ${ }^{b}$ & $\begin{array}{c}\mathrm{TMH}^{\mathrm{c}} \\
\text { (except for SP) }\end{array}$ \\
\hline Probable extracellular protein & Sec & MRKVTLLAAGLVAAAGLVVPATAANA & \\
\hline Protein X2 & $\mathrm{Sec}$ & MQKLRT IVVAAAVAALPVVAAVPANA & \\
\hline Hypothetical protein RHA1_ro05477 & $\mathrm{Sec}$ & MKLRKFAATSALVIAAMGVGAGTAYA & $\begin{array}{l}140-162 \\
169-191\end{array}$ \\
\hline VapD & Sec & MVRARAFGRLFTFLLAVAVIATVSMGGANA & \\
\hline VapA & Sec & MKTLHKTVSKAIAATAVAAAAAMIPAGVANA & \\
\hline Hypothetical protein RHA1_ro04854 & $\mathrm{Sec}$ & MGRRVERMVGTALGGLVAAATVFASGGVAAA & \\
\hline Hypothetical protein nfa 45220 & $\mathrm{Sec}$ & MAKFDIKRTIGTVAATAALVAAPFALSTGTANA & 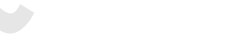 \\
\hline Protein X4 & $\mathrm{Sec}$ & VLKTTPRLRWLLVAVLSVVTMASCGAGLAPQAQA & \\
\hline Hypothetical protein RHA1_ro05669 & $\mathrm{Sec}$ & VSPFARINTARSPLLYVVVAALFATLLVGGGLVVT & \\
\hline Probable resuscitation-promoting factor & $\mathrm{Sec}$ & MSGRHRKPTTTGRTVAKVAVTGAIMGVGGVAFAGTANA & \\
\hline Probable mycolyl transferase 4 & Sec & MRTHRPGSTHRLKKRLIGLVAAALLLPALTAVTGTTTANA & \\
\hline Hypothetical protein RHA1_ro05216 & $\mathrm{Sec}$ & VPAPLHLKSCRPLSFHRVRSTLLGAAVAATVAASLAACGSIDSAGNTLTVPSPSSSTTTPAAK & \\
\hline Probable mycolyl transferase 2 & Tat & MWGSDPRRAARRRLRRGVVGASLAALVALPLAGEAAA & \\
\hline Cholesterol oxidase ChoE & Tat & MTDSRANRADATRGVASVSRRRFLAGAGLTAGAIALSSMSTSASA & \\
\hline Probable mycolyl transferase 1 & Tat & MRSGLERSSYRAGTEGRWRRRALSVAAAALVMPIAAGITSVTAGA & \\
\hline Hypothetical protein RHA1_ro04050 & Tat & LPHRRPKNS IVLAAVAAVAVATPFAVQA & \\
\hline Hypothetical protein RHA1_ro01045 & Tat & MRRSIGESLRRATAVGAAFALTALVPAVASA & \\
\hline Probable mycolyl transferase 3 & Tat & MRVTQKSRRLKALIGATTAAVAALPVFVGAGVASA & \\
\hline Hypothetical protein RHA1_ro06188 & Tat & MNRRTFLGAAGVGALGISALPLVGNRSWNPLAAQARA & \\
\hline Probable protease & Tat & MRIPLAPRAAVHSFARRVAVVGSSALLVLVPLSASAQA & \\
\hline Hypothetical protein RHA1_ro05704 & Tat & VSSTSPADREGSFVRRSTLGAGAAVAAAI I GIGVAPTACA & \\
\hline Probable lipoprotein & Tat & MKGCGMAGSKWRLGVRRMVAGVVAAAGLTAGVAVMSAPAASA & \\
\hline Protein X1 & Tat & MIRRWWRCSSKSMSMMPRRKNGPIRKPQAGSFANAFCRFIATA & \\
\hline Probable stage II sporulation protein & Tat & MRSEPMATPRLRISADRVLRRRRPGRRPSRSVGRLAALGLVPALAVGA & \\
\hline Hypothetical protein RHA1_ro03156 & & None & $61-83$ (N-terminal) \\
\hline Alkyl hydroperoxide reductase & & None & \\
\hline Amidase AmiC_1 & & None & \\
\hline Catalase & & None & \\
\hline Cell division initiation protein & & None & \\
\hline Chaperonin Cpn10 & & None & \\
\hline Cold shock protein A & & None & \\
\hline Dihydrolipoyl dehydrogenase & & None & \\
\hline DNA-directed RNA polymerase $\alpha$-subunit & & None & \\
\hline Elongation factor $\mathrm{G}$ & & None & \\
\hline Elongation factor TU & & None & \\
\hline Chaperonin GroEL2 & & None & \\
\hline Hypothetical protein RHA1_ro05154 & & None & \\
\hline Hypothetical protein RHA1_ro06358 & & None & \\
\hline Peptidyl-prolyl cis-trans isomerase & & None & \\
\hline Phosphomannomutase & & None & \\
\hline Probable nonspecific lipid-transfer protein & & None & \\
\hline Probable thioesterase & & None & \\
\hline Protein X3 & & None & \\
\hline Protein X5 & & None & \\
\hline Protein X6 & & None & \\
\hline Probable secreted protein (PSP) & & None & \\
\hline $30 \mathrm{~S}$ ribosomal protein $\mathrm{S} 1$ & & None & \\
\hline Short-chain dehydrogenase/reductase & & None & \\
\hline
\end{tabular}

Short-chain dehydrogenase/reductase

${ }^{\mathrm{a}}$ Sec, protein secretion system; Tat, twwin-arginine translocation system.

${ }^{\mathrm{b}}$ Signal peptide as deduced from sequence analysis with the SignalP 3.0 and TatP 1.0 algorithms (www.expasy.org). Only results with score $\geq 0,8$ were taken into consideration. The consensus motif recognized by TatP1.0 algorithm RRX[FGAVML][LITMVF] is underlined. The two invariant arginines are enlarged. The recognition sequence of the SPases I at position -1 to -3 relative to the cleavage site is indicated in bold.

c TMH, transmembrane helix as predicted from sequence analysis with the TMHMM 2.0 algorithms (www.expasy.org). Their position in the sequence is indicated.

${ }^{\mathrm{d}}$ These signal peptides contain a complete or incomplete Tat motif, not recognized by the TatP1.0 algorithm. 